\title{
Torture based on discrimination in Chile.
}

\section{The hunger strike of Mapuche political prisoners and the case of machi Celestino Cordova.}

\author{
Jesús Antona Bustos*
}

Of the approximately 40 Mapuche political prisoners currently serving sentences in Chilean jails, more than half have either gone on, or are currently on, hunger strike. The first prisoners to adopt such a measure did so on May 4. They are taking in liquids, but no solids, and so the state of health of many has now reached a critical level. Following substantial international pressure, the Chilean government has offered some minor prison benefits, however, there is no sign of measures to address neither the reasons for the strike, nor the torture perpetrated for reasons of discrimination that the Mapuche prisoners continue to suffer.

The Mapuche prisoners initially demanded to be afforded equal access to the penitentiary measures taken to confront the coronavirus. These were applied to more than 13,000 non-Mapuche prisoners through different formulas: pardons, parole, change of precautionary measures, etc., from which all Mapuche prisoners were excluded. The hunger strike that began as a result of this exclusion, has increased in its demands, which go beyond the coronavirus itself. Those striking demand the freedom of all political prisoners under the argument that the legal processes in which they

\footnotetext{
*) Professor of American Anthropology at the Complutense University of Madrid.

Correspondence to: antona.jesus@gmail.com https://doi.org/10.7146/torture.v30i2.122540
}

have been accused are based on judicial procedures of dubious legality and are legitimised by a racist and tortious interpretation of the nation's Anti-Terrorist Law. Their demands also refer to the government's non-compliance with ILO Convention 169, the Indigenous and Tribal People's Convention, which recommends that states should give preference to methods of punishment other than confinement in prison, preferably allowing them to remain in their communities and according to their own cultural traditions. The repeated refusals of the Sebastián Piñera government to address these claims have highlighted the existence of a discriminatory prison policy. The various human rights organisations, citizens' groups and indigenous organisations that have joined the international protest have described the Chilean state's actions as cruelty. In addition to justice processes of dubious legality, the treatment of Mapuche prisoners in prison is also a matter of concern.

The current problem is one of déjà $v u$, and must be framed in the context of the so-called "Mapuche conflict", which was initiated by the Chilean elites against the indigenous people when they decided to invade the "Mapuche Country" and incorporate the indigenous territories into the sovereignty of the new nation, occupy its lands and assimilate its inhabitants into the discipline of the new republic. The Mapuche consider that they are 
political prisoners for ethnic reasons, since their imprisonment is related to indigenous demands: cultural rights, autonomy, land restitution, control of their ancestral territories. The Chilean authorities, for their part, do not recognise the existence of political prisoners in their country, although, paradoxically, they apply discriminatory treatment specifically to prisoners of Mapuche origin.

Although denied a thousand times over, the coronavirus pandemic has brought the evidence of racism and monoculturalism in the state to light, despite the official narrative on interculturality. The sensitivity of the current government towards the Mapuche prisoners is very different from the indolent penitentiary policy observed towards those convicted of crimes against humanity or the carabineros and military involved in repressing acts of mourning, especially against the "Indians".

The most emblematic case that has captured the attention of the international media is that of machi Celestino Cordova, sentenced to 18 years in prison in the so-called Luchsinger-Mackay case. His status as a traditional religious and therapeutic authority has centred the response of the prisoners and the Mapuche society on his person. The case involving this machi takes its name from the murder of an elderly couple, Werner Luchsinger and Vivian Mackay. The couple perished in a fire, when on January 4, 2013, several hooded men attacked and set fire to their house located on the Lumahue estate (Vilcun Commune). The Luchsinger-Mackay family is a powerful family of landowners in the south of Chile who have regularly clashed with the Mapuche, as many of their properties are located on lands that historically belonged to them. The most notorious confrontation was the one that, five years earlier, led to the death of the young Mapuche, Matías Catrileo, who was shot down by the carabineros during his attempt to occupy one of the properties belonging to this family of landowners.

The commotion caused by this attack amongst policitians and the Chilean public alike and marked by the rise to power of Sebastián Piñera, a supporter of the "iron fist" against the Mapuche, led to the arrests being rushed, with 11 ethnic Mapuche people initially charged with arson of the farm. Five years later, the Temuco Trial Court acquitted all of the accused, except for machi Celestino Córdova, who had already been sentenced to 18 years in prison. The primary evidence against him was a gunshot wound he had sustained less than two kilometres from the area of the attack. However, it was not possible to clarify what happened in the interval, whether the wound was related to the event itself, and whether the bullet came from Luchsinger's weapon, with which he had allegedly tried to defend himself.

The acquittal of the rest of the accused was based on the following arguments: the existence of "an elaborate and coordinated plan" to provoke fear among the farmers in the area was not demonstrated; there was no direct evidence to place the accused at the scene of the crime; the investigation of the case and the collection of evidence "suffered from insurmountable defects". In fact, the only basis for the accusation came from the testimony of one of the defendants, José Peralino Huinca, who, as he later stated when he tried to retract his statement, was forced to testify under pressure and torture. The veracity of his coerced account was questioned, both because of its technical aspects (despite having the appropriate means, it was not recorded), and because of the way in which it was obtained (secrecy, the aforementioned allegations of torture and the offer of reduced sentences). Furthermore, the experts at the trial noted that this community member could not read and had a cognitive deficit. 
However, despite the acquittal, several of the accused continued to be held in pre-trial detention while their appeal was processed by the Public Prosecutor's Office, as the crimes were classified as "terrorism". The most widespread case was that of machi Francisca Linconao, an elderly traditional authority who, in addition to being held in pre-trial detention, was subjected to aggressions, searches, threats, fabrication of false evidence, espionage, etc. Part of this process was the so-called Huracán case: a police operation conceived by the carabineros to spy on indigenous human rights defenders and fabricate false evidence against Mapuche activists. In the end, machi Francisca Linconao was acquitted, and the only other people convicted, besides machi Celestino Córdova, were brothers Luis and José Trancal (life imprisonment) and the aforementioned José Peralino, who received only five years for having collaborated as a co-criminal informant.

The hunger strike of the Mapuche prisoners has placed the figure of the machi, Celestino Cordova at the centre of current political and legal discourse. His request is to be allowed to serve his sentence in his community and near his rewe (ritual post that embodies the spirit, strength and health of the community) in order to be able to attend to his therapeutic and religious functions and responsibilities with the members of his territory or lof. It must be taken into account that according to the vernacular conception of the disease, the Mapuche communities are also at high risk due to the Covid-19 pandemic.

The machi (they can be men or women) are the people in charge of guarding and caring for the rewe, which is the cosmic axis that brings together the different floors and forces of the universe, and from there emanates their strength (newen) to fight evil and guarantee the physical and spiritual health of the lof mapu (territory) and the lof che (all those who live together in that space). But the rewe must be renewed from time to time in order to restore its strength by performing a community ritual called geikurewen, without which it is not possible to maintain collective well-being because the machi becomes ill when he loses his protective spirit (filew). If that happens, the community itself is exposed to illness and is unable to cope with internal conflicts. It is obvious, therefore, that the Mapuche are spiritually uneasy as they find themselves defenceless against an unknown and devastating evil, imported from the non-Mapuche world, wigka kuxan, which, according to native taxonomy, is a disease of "whites" or "foreigners".

Machi Celestino has argued before the authorities that the removal of his rewe and his community causes him great suffering. In fact, he considers it a conscious form of torture to break his spirit, which has also caused him a serious illness: Kisu kuxan (a disease typical of the Mapuche that derives from a cultural transgression). That is why the machi continued with the strike until its last consequences. In any case, if the rewe is not renewed, he will die because of a disease that is typical of female machi (machi kuxan), which usually manifests itself by not fulfilling the obligations of one's role. Therefore, if the cause of the transgression produced by the machi's disease-in this case by performing the rewe renewal ritual-is not alleviated, his suffering will inevitably lead to his death, and that is a powerful reason for understanding the machi's wholeness.

Understanding what it means for a person of any religious tradition to violate their liturgical and spiritual obligations and the effects that this has on their mental health, allows us to understand the extent of the damage that this situation generates and why this spiritual guide is considered to be subjected to a type of culturally-based torture. The action taken against him, like that of torture in general, 
aims to set an example for all Mapuche people. Therefore, what is at stake, besides the physical integrity of the prisoners on hunger strike, are their fundamental human rights, as well as the religious freedom and the right to health of all Mapuche people.

In a situation like the one caused by the COVID-19 pandemic, the deprivation of freedom of this religious authority is a collective punishment for all Mapuche people.

The repressive strategy directed against socio-political $(\log k o)$ and religious (mach $\imath$ ) authorities is part of the modus operandi of the "stick and carrot" policy that alternate Chilean governments have tried to stifle cycles of ethnic emergence. Cases such as that of logko Pascual Pichun and Aniceto Norín, machi Juana Calfunao and Francisca Linconao provide good background for understanding what is happening today in the case of machi Celestino Córdova. These cases have made their way around the world and have been the subject of multiple condemnations in the reports of the different UN Rapporteurs and the main organisations of human rights defenders. Ultimately, the intervention of the Inter-American Human Rights System has forced the Chilean justice system to revoke various convictions, by questioning the legality of the processes followed, drawing attention to the harshness with which the Mapuche are judged and the discriminatory practices against this ethnic group. Unfortunately, international justice is slow and costly and there has not been a single case in which those involved have not had to endure years of deprivation of liberty, torture, searches, harassment and humiliating treatment, while their families and neighbours have experienced a distressing ordeal until they were free from police and judicial persecution.

In short, it is urgent that the Chilean government does not prolong any further the suffering of these people, which we consider to be culturally based and discriminatory in nature, by addressing the problem with the Mapuche from a political rather than a law enforcement perspective. To this end, the first step is to solve the unjustifiable prison situation of the Mapuche prisoners. 